\title{
Simposio
}

\section{VIEJOS Y NUEVOS CONCEPTOS EN INMUNIDAD A PARÁSITOS}

\section{Schistosoma mansoni antigens down-modulate the inflammatory response associated with immune-mediated diseases}

\author{
Maria IIma Araujo ${ }^{1,2,3}$, Luciana Cardoso ${ }^{1,2,4}$, Ricardo Oliveira ${ }^{1,2}$, Aline Báfica $^{1}$, Robson Souza $^{1}$, \\ Alfredo Góes $^{5}$, Sérgio Oliveira ${ }^{5}$, Edgar Carvalho ${ }^{1,2,3}$ \\ 1 Serviço de Imunologia, Universidade Federal da Bahia, Salvador, Brasil \\ 2 Instituto Nacional de Ciências e Tecnologia em Doenças Tropicais, Brasil \\ 3 Escola Bahiana de Medicina e Saúde Pública, Salvador, Brasil \\ ${ }^{4}$ Departmento de Ciências da Vida, Universidade do Estado da Bahia, Salvador, Brasil \\ ${ }^{5}$ Departamento de Bioquímica e Imunologia, Universidade Federal de Minas Gerais, Belo Horizonte, \\ Brasil
}

Epidemiologic evidence has accumulated suggesting that helminth infection or their products protect against the development of allergic and autoimmune diseases. The mechanisms underlying this protection may include regulatory cells and cytokines. Considering that Schistosoma sp. has been one of the most important helminth associated with strong induction of regulatory mechanisms, and also considering our data which have demonstrated that $S$. mansoni infections are associated with a poor response to allergy skin-prick tests and with low asthma pathology, we hypothesized that antigens of $S$. mansoni are able to modulate the inflammatory response in type $2 \mathrm{CD}^{+} \mathrm{T}$ (Th2) cellsmediated diseases such as asthma.

We have tested in the in vitro and in experimental studies the ability of the recombinant $S$. mansoni antigens Sm22.6, Sm29 and PIII in modulating the inflammatory response in atopic asthma.

The Sm22.6 antigen is a soluble protein from the tegument, present in the life cycle of the worm with the exception of the egg. Sm29 is a membranebound glycoprotein found on the tegument of the adult worm during the lung stage of $S$. mansoni infection, while PIII is a fraction of $S$. mansonisoluble adult worm antigen (SWAP). These antigens have been tested as vaccine to prevent schistosomiasis and/or liver pathology associated with the disease in murine models.

We found that these proteins induce IL-10 in S. mansoni infected asthmatics. Moreover, in a murine model of OVA induced airway inflammation, immunization with Sm22.6, PIII and Sm29 lead to a reduction in the number of inflammatory cells, eosinophils and OVA-specific IgE, compared to non- immunized mice. The S. mansoni antigens are also capable to suppress the in vitro Th2-inflammatory response in uninfected asthmatics. Additionally, the ability of $S$. mansoniantigens in down-modulate the in vitro Th1-inflammatory response in cutaneous leishmaniasis patients are currently been tested.

Leishmaniasis is an infectious disease caused by a protozoan from the genus Leishmania spp. It is one of the most severe infectious diseases, affecting 12 million people worldwide with an incidence of skin disease in about 1.5 million cases per year. Four different forms of tegumentary leishmaniasis are described: cutaneous, mucosal, diffuse and disseminated leishmaniasis. Cutaneous leishmaniasis is the most common clinical manifestation, characterized by one to several skin lesions in exposed areas, with an absence or small number of parasites. Control of Leishmania spp. infection depends on the immune response mediated by Th1, which produce interferon-gamma (IFN- $\gamma$ ) and are able to activate tissue macrophages. However, when this immune response is deregulated and there is a high production of IFN- $\gamma$ and tumor necrosis factor-a (TNF-a), intense tissue damage occurs, leading to development of cutaneous and mucosal leishmaniasis. Considering the potential of S. mansoni antigens to prevent some Th1mediated diseases, we have evaluated the effects of the addition of $S$. mansoniantigens to the immune response induced by soluble Leishmania sp antigen (SLA) in cutaneous leishmaniasis patients.

We examined IFN- $\gamma$, TNF- $a$, IL-12 and IL-10 production by cells of cutaneous leishmaniasis patients stimulated in vitro with the soluble Leishmania antigen (SLA) in the presence or 
absence of the recombinant $S$. mansoni antigens Sm29 and tetraspanin 2 (SmTSP-2) and also PIII. The addition of Sm29, SmTSP-2 and PIII to the cell cultures reduced the levels of IFN- $\gamma$ in high number of patients, independently of the number and size of lesions.

Although to a lesser extent, the three antigens used in the study were also able to decrease the production of TNF-a by peripheral blood mononuclear cell from cutaneous leishmaniasis patients in response to SLA. The modulation of IFN- $\gamma$ and TNF-a production in cultures stimulated with SLA in the presence of $S$. mansoni antigens was generally followed by an increase in IL-10 production. The use of $S$. mansoni antigens also resulted in a lower frequency of classical and proinflammatory monocytes expressing IL-12 and TNF-a, while increased the frequency of monocytes expressing IL-10 and IL-10 receptor.

The antigens used in this study down-modulated the in vitro proinflammatory response induced by SLA in a group of cutaneus leishmaniasis patients. The S. mansoni antigens evaluated in these studies induced the production of regulatory cells and cytokines and down-modulated the Th2 and Th1 immune response which participates, respectively in the pathology of asthma and cutaneous leishmanisis.

\section{Recommended readings}

1. Araujo MI, Campos RA, Cardoso LS, Oliveira SC, Carvalho EM. Immunomodulation of the allergic inflammatory response: new developments. Inflamm Allergy Drug Targets. 2010;9:73-82.

2. Araujo MI, Hoppe B, Medeiros M Jr., Alcantara L, Almeida MC, Schriefer A, et al. Impaired T helper 2 response to aeroallergen in helminth-infected patients with asthma. J Infect Dis. 2004;190:1797-803.

3. Araujo MI, Hoppe BS, Medeiros M Jr., Carvalho EM. Schistosoma mansoni infection modulates the immune response against allergic and auto-immune diseases. Mem Inst Oswaldo Cruz. 2004;99:27-32.

4. Bacellar O, Lessa H, Schriefer A, Machado P, Ribeiro de Jesus A, Dutra WO, Gollob KJ, Carvalho EM. Up-regulation of Th1-type responses in mucosal leishmaniasis patients. Infect Immun. 2002;70:673440.
5. Capron A, Dombrowicz D, Capron M. Helminth infections and allergic diseases: From the Th2 paradigm to regulatory networks. Clin Rev Allergy Immunol. 2004;26:25-34.

6. Cardoso LS, Oliveira SC, Goes AM, Oliveira RR, Pacifico LG, Marinho FV, et al.. Schistosoma mansoni antigens modulate the allergic response in a murine model of ovalbumin-induced airway inflammation. Clin Exp Immunol. 2010;99:1-9.

7. Cardoso LS, Oliveira SC, Pacifico LG, Goes AM, Oliveira RR, Fonseca CT, et al. Schistosoma mansoni antigen-driven interleukin-10 production in infected asthmatic individuals. Mem Inst Oswaldo Cruz. 2006;101(Suppl.1):339-43.

8. Liu Q, Sundar K, Mishra PK, Mousavi G, Liu Z, Gaydo $A$, et al. Helminth infection can reduce insulitis and type 1 diabetes through CD25- and IL-10-independent mechanisms. Infect Immun. 2009;77:5347-58.

9. Oliveira RR, Gollob KJ, Figueiredo JP, Alcântara LM, Cardoso LS, Aquino CS, et al.. Schistosoma mansoni infection alters co-stimulatory molecule expression and cell activation in asthma. Microbes Infect. 2009;11:223-9.

10. Osada Y, Shimizu S, Kumagai T, Yamada S, Kanazawa T. Schistosoma mansoni infection reduces severity of collagen-induced arthritis via down-regulation of proinflammatory mediators. Int J Parasitol. 2009;39:45764.

11. Pacifico LG, Marinho FA, Fonseca CT, Barsante MM, Pinho V, Sales-Junior PA, et al. asthma in a murine model: a major role for CD4+ CD25+ Foxp3+ T cells independent of interleukin-10. Infect Immun. 2009;77:98-107.

12. Ribeiro de Jesus A, Almeida RP, Lessa H, Bacellar O, Carvalho EM. Cytokine profile and pathology in human leishmaniasis. Braz J Med Biol Res. 1998;31:143-8.

13. Strachan DP. Family size, infection and atopy: the first decade of the "hygiene hypothesis". Thorax. 2000;55(Suppl.1):S2-10.

14. van den Biggelaar $A H$, van Ree $R$, Rodrigues LC, Lell B, Deelder AM, Kremsner PG, Yazdanbakhsh M. Decreased atopy in children infected with Schistosoma haematobium: a role for parasite-induced interleukin10. Lancet. 2000;356:1723-7.

15. Yazdanbakhsh M, Kremsner PG, van Ree R. Allergy, parasites, and the hygiene hypothesis. Science. 2002;296:490-4. 


\title{
Trichinella spiralis: relación de la infección con el sistema inmunitario de mucosas
}

\author{
María Virginia Gentilini, Stella Maris Venturiello \\ Facultad de Farmacia y Bioquímica, Universidad de Buenos Aires, Buenos Aires, Argentina
}

Los mecanismos inmunológicos de protección del huésped contra el nematodo Trichinella spiralis están dirigidos contra los vermes adultos y contra las larvas recién nacidas o migrantes.

El ataque inmunológico contra el verme adulto se manifiesta por un rechazo acelerado del intestino (1) mediado por linfocitos T y mastocitos (2). Este fenómeno coincide con la máxima respuesta inflamatoria intestinal caracterizada por citocinas proinflamatorias, aumento en el recambio de enterocitos, células caliciformes, eosinófilos y células de Paneth (3).

Las larvas recién nacidas o migrantes son destruidas en presencia de células activadas por anticuerpos específicos mediante el mecanismo de citotoxicidad celular dependiente de anticuerpos (4).

Considerando:

1) que el primer estímulo antigénico en la triquinelosis es en la mucosa intestinal;

2) que el sistema inmune de las mucosas es un sistema integrado en el cual la inmunización en un sitio confiere inmunidad en otro (5);

3) que las larvas recién nacidas o migrantes durante su migración atraviesan el pulmón (6) y que dicho órgano es sugerido por algunos autores como sitio de retención y destrucción parasitaria (7), y

4) que las larvas recién nacidas o migrantes son destruídas mediante citotoxicidad celular dependiente de anticuerpos sin que se conozca el sitio del organismo en donde ocurre este fenómeno, nuestro objetivo fue determinar en ratas Wistar infectadas si el pulmón puede actuar como órgano de retención y destrucción parasitaria.

Paraesto se caracterizóla respuestainmunológica en el pulmón durante la fase intestinal (0-13 días después de la infección) de la infección con $T$. spiralis.

Estudios histológicos e inmunohistoquímicos

Nuestros resultados demostraron el rápido desarrollo de una respuesta inflamatoria pulmonar simultánea al proceso inflamatorio intestinal, caracterizada por infiltrados de mastocitos y eosinófilos, hiperplasia de linfocitos $T$ del lavado broncoalveolar y de las células caliciformes con producción de moco. El fenotipo celular presentado es de tipo Th2 con incremento en las poblaciones celulares $\lg \mathrm{E}^{+}, \mathrm{LT}_{\mathrm{CD}} 4^{+}(\mathrm{lg} \mathrm{E}+: 197 \pm 19$ vs. $88 \pm 11$; LT $\mathrm{CD}^{+}: 307 \pm 32$ vs. $195 \pm 11$ del número de células $/ 15$ campos, animales infectados vs. control).

Cinética de aparición de citocinas, quimioquinas en extractos pulmonares mediante ELISA e inmunoelectrotransferencia

Se observaron niveles elevados de TNFa 1 a 2 días después de la infección (485 $\pm 58-370 \pm 54$ vs. $140 \pm 43 \mathrm{pg} / \mathrm{ml}$ ); de INFY, 1 a 6 días después de la infección (162 $\pm 12-233 \pm 35$ vs. $80 \pm 7$ pg/ $\mathrm{ml}$ ); de IL-10, 3 a 6días después de la infección (142 $\pm 12-124 \pm 10$ vs. $68 \pm 4 \mathrm{pg} / \mathrm{ml})$; de TGF- $\beta, 6$ a13 días después de la infección (10457 \pm 1512 , $13276 \pm 1517$ vs. $7662 \pm 1001 \mathrm{pg} / \mathrm{ml}) ; \mathrm{IL}-4$, elevada desde el 1 día después de la infección, se encontró significativamente elevada al 6 y 13 días después de la infección $(111 \pm 25,239 \pm 86$ vs. $11 \pm 7 \mathrm{pg} / \mathrm{ml})$; IL-13 1-6 días después de la infección (16 \pm 2 $9 \pm 3 \mathrm{RP}$, relación de densidades ópticas teniendo en cuenta la presencia de $\beta$ actina); IL-5 e IL-12 permanecieron ligeramente elevadas durante el período estudiado.

La CCL11, quimiocina involucrada en la migración de eosinófilos (8), se encontró elevada 1 a 13 días después de la infección (1809 $\pm 148-1727 \pm 285$ vs. $286 \pm 25 \mathrm{pg} / \mathrm{m}$ ) y la CCL28, quimiocina involucrada en el tráfico de células inmunes (9), se halló elevada 1 a 2 días después de la infección (13 $\pm 0-15 \pm 4 R P)$.

Cinética de aparición de inmunoglobulinas totales y anticuerpos anti-productos de excreción-secreción (anti-PES-LM) en extractos pulmonares mediante ELISA

Se halló IgA e lgE total desde el 1 día después de la infección y durante el periodo estudiado, lgG1 e lgG2a total desde el 3 día después de la infección, con niveles significativamente elevados el día 13 después de la infección (IgA total: 1628 \pm 165 vs. $562 \pm 85 \mu \mathrm{g} / \mathrm{ml}$; IgE total: $5810 \pm 1604$ vs. $6.8 \pm 3.44$ $\mathrm{ng} / \mathrm{ml}$; lgG1: $17.48 \pm 0.33$ vs. $1.90 \pm 0.04 \mathrm{ng} / \mathrm{ml}$; IgG2a: $18.23 \pm 0.64$ vs. $2.40 \pm 0.13 \mathrm{ng} / \mathrm{ml}$ ). Se detectó presencia de $\lg A$ e $\lg E$ anti-PES-LM en todos los días estudiados; IgG1 a partir del 3 día después de la infección e lgG2a del 1 al 3 día después de la infección; lgE e lgG1 específicas presentaron una significativa disminución al 6 día después de la infección. 
Secreción de inmunoglobulinas totales y antiPES-LM mediante ELISPOT

Se detectaron células secretoras de todos los isotipos durante el período estudiado con sólo un aumento de las células secretoras de lgE e lgG1 al 13 día después de la infección, células secretoras de $\lg A$, IgE e IgG2a específicas a partir del día 2 después de la infección y de lgG1 el día13 después de la infección.

Presencia y niveles de anticuerpos antisuperficie de larvas recién nacidas o migrantes en sueros mediante IFI

En sueros, se detectó al 6 día después de la infección lgE e lgG2a anti- larvas recién nacidas o migrantes con título de 4 en el $63 \%$ y $13 \%$ de los sueros analizados; al día 13 después de la infección en todos los isotipos estudiados: IgE en el $100 \%$ de los sueros con título de 128; IgG1, $\lg 22 a$ en el $86 \%$ de los sueros e $\lg A$ en el $71 \%$ con títulos de 64.

Estudio del pulmón como órgano de retención y destrucción parasitaria

Para determinar si el pulmón actúa como un órgano de retención parasitaria, se evaluó mediante microscopía óptica la presencia del parásito en cortes de tejido pulmonar y en suspensiones pulmonares a los 6 y 13 días después de la infección. Se hallaron larvas recién nacidas o migrantes en parénquima y alvéolos y se recuperaron de pulmones en ambos después de la infección.

En el estudio del pulmón como órgano de destrucción parasitaria, se evaluó la capacidad citotóxica de células provenientes de lavado broncoalveolar y de parénquima frente a larvas recién nacidas o migrantes. Se realizaron ensayos de citotoxicidad celular en presencia y ausencia de suero citotóxico de referencia con medición del porcentaje de mortalidad de las larvas recién nacidas o migrantes. Los resultados se presentan en la tabla 1.

Los resultados demostraron que las células pulmonares son capaces de mediar la muerte de las larvas recién nacidas o migrantes. las células provenientes del lavado broncoalveolar, mediante citotoxicidad directa mientras que las células de parénquima en presencia de anticuerpos específicos. Las células del lavado broncoalveolar mostraron una gran capacidad citotóxica in vitro ya que fueron capaces de destruir al parásito a las 4 horas.

El estudio de la actividad biológica de las células del parénquima y de los sueros provenientes de animales infectados, el mismo día después de la infección, mostraron porcentajes de mortalidad de larvas recién nacidas o migrantes superiores al alcanzado con los sueros de ratas no infectadas (porcentaje de mortalidad al 6 día después de la infección: $19 \pm 2$ vs. $7 \pm 2$ y 13 días después de la infección: $41 \pm 6$ vs. $18 \pm 2$, presencia vs. ausencia de anticuerpos).

Los resultados demuestran que el pulmón puede actuar como un órgano de retención y destrucción parasitaria y sugieren que las larvas recién nacidas o migrantes al salir del intestino y en su vehículo hacia el músculo estriado, con opsonización o no por anticuerpos específicos, se encuentran con un pulmón sensibilizado que permitiría sólo el pasaje de aquellas larvas recién nacidas o migrantes que puedan evadir el ataque (10).

Nuestros resultados indican, además, que durante la infección intestinal con $T$. spiralis existen dos señales responsables de la sensibilización del pulmón:

- Una primera, causada por el estímulo antigénico en la mucosa intestinal, relacionada con el

Tabla 1. Actividad citotóxica de células pulmonares frente a larvas recién nacidas o migrantes durante la fase intestinal de la infección por Trichinella spiralis.

\begin{tabular}{lcccc}
\hline & & \multicolumn{3}{c}{$\%$ de Mortalidad de LRN } \\
\cline { 3 - 5 } Días después & Suero citotóxico & Células de BAL & Células de parénquima \\
de la infección & de referencia & $\mathbf{4}$ horas & $\mathbf{2 4}$ horas & $\mathbf{2 4}$ horas \\
6 & Ausencia & $13,1 \pm 1,6$ & $25,4 \pm 3,6$ & $7 \pm 2$ \\
& Presencia & $15,6 \pm 2,5$ & $26,4 \pm 3,6$ & $50 \pm 7$ \\
13 & Ausencia & $21,0 \pm 1,5$ & $22,2 \pm 1,1$ & $18 \pm 2$ \\
& Presencia & $22,0 \pm 2,1$ & $30,1 \pm 3,7$ & $47 \pm 4$ \\
Control & Ausencia & $1,1 \pm 0,7$ & $6,5 \pm 1,3$ & $6 \pm 3$ \\
& Presencia & $10,8 \pm 0,3$ & $23,5 \pm 2,4$ & $30 \pm 3$ \\
\hline
\end{tabular}

LNR: larvas recién nacidas o migrantes; BAL: broncho-alveolar lavage 
sistema inmune asociado a las mucosas. Durante esta etapa se observa producción y secreción de $\lg E$, IgA total y anti-PES-LM, citocinas inflamatorias, quimiocinas CCL11 y CCL28 y presencia de infiltrados celulares.

- Una segunda, producida por el estímulo antigénico in situ debido al pasaje de la larva recién nacida o migrante por el pulmón. Esta etapa presenta un perfil de tipo Th2 y se caracteriza por máximo infiltrado de eosinófilos, predominio de CCL11 e IL-4, altos niveles de $\lg E>\lg G 1>\lg G 2 a>\lg A$ total, producción y secreción de anti-PES-LM y actividad efectora de células pulmonares.

Así, durante una infección por T. spiralis ocurren mecanismos efectores dirigidos hacia los vermes adultos en el intestino y hacia las larvas recién nacidas o migrantes en el pulmón. Estas observaciones constituyen las bases para el desarrollo de estrategias de inmunoprotección.

\section{Referencias}

1. Ierna MX, Scales HE, Saunders KL, Lawrence CE. Mast cell production of IL-4 and TNF may be required for protective and pathological responses in gastrointestinal helminth infection. Mucosal Immunol. 2008;1:147-55.

2. Suzuki T, Sasaki T, Takagi H, Sato K, Ueda K, The effectors responsible for gastrointestinal nematode parasites, Trichinella spiralis, expulsion in rats. Parasitol Res. 2008;103:1289-95.

\section{Leishmania-macrophage interaction: a signaling story}

\section{Martin Olivier}

\section{McGill University and the Research Institute, McGill University Health Centre, Montreal, Canada}

Apart from the impact of Leishmania spp. on world health, leishmaniasis represents an elegant infection model that can teach us a lot about hostparasite interactions and immune evasion.

This parasite has the ability to enter host macrophages (MØs) safely and replicate inside the very same phagocytes that were recruited to destroy it. The inability of $\mathrm{M} \varnothing \mathrm{s}$ to kill the parasite and activate cells of the adaptive immune system is a product of the parasite's long-reported capacity to alter several key signalling pathways in the host. Many signalling alterations are seen early in the course of infection suggesting they start upon the initial contact between the parasite and the $\mathrm{M} \varnothing$. These rapid alterations of signalling pathways serve at least two main functions: firstly, inhibition of $\mathrm{M} \varnothing$ killing mechanisms that are triggered upon phagocytosis of foreign particles (e.g., production of reactive oxygen species) and secondly, inhibition of leishmanicidal functions that can be triggered in response to $\mathrm{M} \varnothing$ activation in infected tissues in response to stimuli such as lipopolysaccharides (LPS) or interferon- $\gamma$ (IFN- $\gamma$ ) (e.g., nitric oxide production).

Very recent work from our laboratory showed that Leishmania gp63 was able to enhance PTP1B activation by cleaving it. PTP-1B activity seems to inhibit $M \varnothing$ activation and help in parasite survival as seen in the delayed onset of footpad swelling and reduced parasite burden in $\mathrm{PTP}^{-1 \mathrm{~B}^{-/-}}$ mice infected with Leishmania major. We further showed that gp63 of Leishmania was able to enhance TC-PTP activation by cleaving it in host MØs. This gp63-mediated TC-PTP cleavage along with the cleavage of PTP-PEST were very recently reported, by our group and M. L. Tremblay's group, 
to occur in fibroblasts infected with Leishmania and were suggested to enhance the catalytic activity of the PTPs in question and/or allow them to access additional substrates that might help the parasite establish itself.

At the signalling level, our laboratory has initially demonstrated that Leishmania was able to rapidly activate host SHP-1 causing SHP-1-mediated JAK2 inactivation in MØs. Additionally, we and others have implicated SHP-1 in the negative regulation of Erk1/2 activity and in the regulation of the downstream TFs NF- $\mathrm{BB}$ and AP-1 during Leishmania infection. At the functional level, our laboratory showed that the injection of PTP inhibitors (bis-peroxovanadium compounds) to mice infected with L. major or Leishmania donovani helped control the infection in a manner dependent on iNOS expression and NO production. Furthermore, we demonstrated that SHP-1-deficient viable motheaten mice, infected with $L$. major, did not develop footpad swelling and had significantly reduced parasitic loads. This decreased pathology was associated with more neutrophil recruitment to the footpad and more iNOS mRNA expression.

As to how Leishmania is able to activate SHP-1, it has been recently suggested by our group, that SHP-1 was shown to be activated via cleavage by the parasite's protease gp63, which gains access to the cytosol by going through the lipid raft of host MØs. In conclusion, it appears that the rapid activation of SHP-1 by Leishmania is a key host evasion step whereby the parasite is able to utilize this phosphatase to negatively regulate several key $M \varnothing$ pathways and render it unresponsive to activating stimuli such as: IFN-y and LPS. By doing so, the parasite is able to block several $M \varnothing$ functions such as NO production and the synthesis of many pro-inflammatory cytokines that can be deadly to the parasite if allowed to be produced.

One of the dangers that Leishmania encounters recruiting and entering $M \varnothing s$ is the ability of these cells to produce free radicals that are deadly to the parasite. Two main free radical molecules have been shown to have leishmanicidal effects: NO and reactive oxygen intermediates (ROIs). NO is produced by NOS which converts one of the terminal nitrogens of the guanidino group of L-arginine to NO producing L-citrulline. The importance of this free radical in leishmaniasis was demonstrated by several groups. An early study showed the ability of activated MØs to kill $L$. major amastigotes by an L-arginine-dependent mechanism. Another study confirmed this observation by showing that
L-NMMA, an L-arginine analogue and inhibitor of the NO pathway, was able to inhibit the leishmanicidal effect of MØs activated in vitro with IFN- $\gamma$ or LPS. The authors also showed the ability of NO in cellfree suspensions to kill the parasite. Importantly, the same group demonstrated the importance of $\mathrm{NO}$ in vivo by rendering resistant CBA mice susceptible to $L$. major infection upon local administration of L-NMMA.

The question that comes to mind next is: how can NO contribute to parasite killing? Modes of action seem to include the ability of NO to cause modifications of proteins, injury to mitochondria, oxidation of membranes, DNA damage, modulation of cytokine production, and interference with maturation of immune cells. Examples of Leishmania proteins inactivated by $\mathrm{NO}$ include the glycolytic enzyme GAPDH and the Krebs cycle enzyme, aconitase, which NO can inhibit through triggering iron loss from its iron-sulfur prosthetic group.

Having discussed the detrimental effects of $\mathrm{NO}$ on Leishmania, it is comprehensible that the parasite is able to block its synthesis in response to stimuli such as IFN- $\gamma$, but how can Leishmania achieve this inhibition? A critical role for host SHP-1 has been proposed. As previously stated, Leishmania has the ability to rapidly activate SHP-1 in infected MØs and by doing so can interfere with several molecules involved in NO production including: JAK2, Erk1/2, and the TFs NF- $\kappa B$ and AP-1. Indeed, SHP-1 deficient $M \varnothing s$ infected with $L$. donovani are still able to produce $\mathrm{NO}$ in response to IFN- $\gamma$ stimulation unlike infected WT MØs which are refractory to a similar stimulation. Expectedly, the IFN- $\gamma$-mediated NO production in infected SHP-1 deficient MØs correlated with successful phosphorylation of JAK2 and Erk1/2, and the activation of NF-kB and AP-1. These findings further elucidate the role of SHP-1 activation in parasite survival and propagation through its ability to contribute to NO inhibition.

Collectively, over the last 15 years, research in our laboratory has accumulated strong evidence that the Leishmania parasite is able to establish itself and propagate within the mammalian host through its ability to alter several key signalling pathways in order to interfere with critical $M \varnothing$ functions that can otherwise threaten parasite survival. One key way Leishmania can do so is by exploiting host negative regulatory mechanisms such as PTPs. The ability of Leishmania to rapidly activate host PTPs such as SHP-1 is a central event contributing to the parasite's ability to inhibit several IFN- $\gamma$ - and LPS- 
mediated functions that are crucial to $\mathrm{M} \varnothing$ activation and to its ability to control and clear Leishmania parasites.

\section{References}

1. Contreras-García I, Gómez MA, Nguyen O, Shio MT, McMaster RW, Olivier M. Leishmania-induced inactivation of the macrophage transcription factor AP-1 is mediated by the parasite metalloprotease GP63. PLoS Pathogens. 2010, e-pub Oct. 15th..
2. Gómez MA, Contreras I, Halle M, Tremblay ML, McMaster RW, Olivier M. The major surface protease of Leishmania is implicated in the modulation of macrophage protein tyrosine phosphatases. Sci Sign. 2009;90:1-12.

3. Olivier M, Gregory DJ, Forget G. Subvervion mechanisms of Leishmania parasite to escape host immune response: A signaling point of view. Clin Microbiol Rev. 2005;18:293-305.

\section{Los linfocitos T en la respuesta crónica a Trypanosoma cruzi}

John M. González', Paola Lasso², Natalia I. Bolaños ${ }^{1}$, Nicolás A. Giraldo', Adriana Cuéllar ${ }^{3}$, Fanny Guzman ${ }^{4}$, Zulma M. Cucunubá ${ }^{5}$, Nubia Roa ${ }^{6}$, Fernando Rosas ${ }^{7}$, Víctor Velasco ${ }^{7}$, María del Carmen Thomas ${ }^{8}$, Manuel Carlos López ${ }^{8}$, Concepción J. Puerta ${ }^{2}$

${ }^{1}$ Grupo de Ciencias Básicas Médicas, Facultad de Medicina, Universidad de los Andes, Bogotá, D.C., Colombia

${ }^{2}$ Laboratorio de Parasitología Molecular, Departamento de Microbiología, Facultad de Ciencias, Pontifica Universidad Javeriana, Bogotá, D.C., Colombia

${ }^{3}$ Grupo de Inmunobiología y Biología Celular, Facultad de Ciencias, Pontifica Universidad Javeriana, Bogotá, D.C., Colombia

${ }^{4}$ Laboratorio de Genética e Inmunología Molecular, Núcleo Biotecnología Curauma, Pontificia Universidad Católica de Valparaíso, Valparaíso, Chile

${ }^{5}$ Grupo de Parasitología, Instituto Nacional de Salud, Bogotá, D.C., Colombia

${ }^{6}$ Facultad de Medicina, Pontificia Universidad Javeriana, Bogotá, D.C., Colombia

7 Clínica Abood Shaio, Bogotá, D.C., Colombia

${ }^{8}$ Departamento de Biología Molecular, Instituto de Parasitología y Biomedicina López Neyra, Consejo Superior de Investigaciones Científicas, Parque Tecnológico de Ciencias de la Salud, Granada, España

La importancia de los linfocitos T CD8+ en el control de la infección por Trypanosoma cruzi ha sido demostrada en modelos animales, en los cuales la eliminación de esta población celular aumenta la carga parasitaria y la mortalidad (Tarleton, 1990). No obstante, la presencia de estos linfocitos en el tejido cardiaco de animales, al igual que en pacientes con cardiopatía chagásica aguda y crónica, sugieren su participación en el daño del miocardio, probablemente mediante sus funciones efectoras como la producción de citocinas y la presencia de gránulos citotóxicos como perforina y fragmentinas (Reis et al., 1993, Silverio et al., 2010).

El procesamiento de antígenos y la presentación a los linfocitos T en el contexto de HLA de clase I ha sido demostrada en la infección con T. cruzi, en células estimuladas usando una mezcla de antígenos crudos del parásito; aunque los porcentajes de estos linfocitos T CD8+ en sangre periférica que reconocen dicho antígeno es bajo, menos de 3.0\% del total (Laucella et al., 2004, Wizel et al., 1998). En la patogénesis de la miocardiopatía chagásica no se conocen los marcadores de migración tisular, ni su especificidad de antígeno en los linfocitos T CD8+.

Con el fin de estudiar la participación de los linfocitos T CD8+ en la inmunidad o patogénesis frente a la infección por $T$. cruzi, se requiere identificar los antígenos que estos linfocitos reconocen para su seguimiento y caracterización funcional. Se han descrito epítopos de unión a HLA de clase I en proteínas parasitarias como en las transialidasas (Martin et al., 2006) y la proteína de $11 \mathrm{kDa}$ de membrana de cinetoplástidos o KMP11 (Diez et al., 2006), especialmente secuencias de unión al alelo HLA-A2. Con la estimulación usando péptidos sintéticos que representan dichos epítopos se evalúa la producción de citocinas como IFN $\gamma$,y mediante el uso tetrámeros de HLA/ péptidos unidos a marcadores fluorescentes, se puede rastrear las células específicas de sangre o tejidos.

Nuestro grupo de investigación ha venido trabajando con el péptido K1, localizado en la región $\mathrm{N}$-terminal de la proteína KMP-11 de $T$. cruzi, el cual se une al HLA-A*0201, subtipo de alta frecuencia en población latinoamericana (Lasso 
et al., 2010). Mediante el estudio de linfocitos de sangre periférica en individuos no infectados con $T$. cruzi y en pacientes con cardiopatía chagásica crónica asintomática y sintomática se ha podido determinar que:

a) el péptido $\mathrm{K} 1$ es procesado naturalmente y reconocido por linfocitos T CD8+ de pacientes con enfermedad de Chagas;

b) la frecuencia de linfocitos T específicos de K1 es muy baja y no diferencian pacientes con cardiopatía según la presencia de síntomas;

c) el péptido K1 induce una baja respuesta de producción de citocinas como IFN $\gamma$ e IL-2;

d) hay degranulación de un porcentaje de los linfocitos en presencia del péptido;

e) la mayoría de linfocitos K1-específicos presentan un fenotipo de linfocitos $T$ de memoria efectora, $y$

f) los pacientes chagásicos presentan una alta frecuencia de linfocitos T CD4+/CD8+o doble positivos en sangre periférica.

\section{Referencias}

1. Diez H, López MC, Thomas MC, Guzmán F, Rosas $\mathrm{F}$, Velazco $\mathrm{V}$, et al. Evaluation of IFN-gamma production by CD8 $T$ lymphocytes in response to the $\mathrm{K} 1$ peptide from KMP-11 protein in patients infected with Trypanosoma cruzi. Parasite Immunol. 2006;28:101-5.

2. Lasso P, Mesa D, Cuéllar A, Guzmán F, Bolaños N, Rosas F, et al. Frequency of specific CD8+ T cells for a promiscuous epitope derived from Trypanosoma cruzi KMP-11 protein in chagasic patients. Parasite Immunol. 2010;32:494-502.

3. Laucella SA, Postan M, Martin D, Hubby Fralish B, Albareda MC, Álvarez MG, et al. Frequency of interferon-gamma-producing $T$ cells specific for Trypanosoma cruzi inversely correlates with disease severity in chronic human Chagas disease. J Infect Dis. 2004;189:909-18.

4. Martin DL, Weatherly DB, Laucella SA, Cabinian MA, Crim MT, et al. T-cell responses to Trypanosoma cruzi are highly focused on strain-variant trans-sialidase epitopes. PLoS Pathog. 2006;2:e77.

5. Reis DD, Jones EM, Tostes S Jr, Lopes ER, Gazzinelli G, Colley DG, et al. Characterization of inflammatory infiltrates in chronic chagasic myocardial lesions: presence of tumor necrosis factor-alpha+ cells and dominance of granzyme A+, CD8+ lymphocytes. Am J Trop Med Hyg. 1993;48:637-44.

6. Silverio JC, de Oliveira-Pinto LM, da Silva AA, de Oliveira GM, Lannes-Vieira J. Perforin-expressing cytotoxic cells contribute to chronic cardiomyopathy in Trypanosoma cruzi infection. Int J Exp Pathol. 2010;91:72-86.

7. Tarleton RL. Depletion of CD8+ T cells increases susceptibility and reverses vaccine-induced immunity in mice infected with Trypanosoma cruzi. J Immunol. 1990;144:717-24.

8. Wizel B, Palmieri M, Mendoza C, Arana B, Sidney $J$, Sette A, Tarleton R. Human infection with Trypanosoma cruzi induces parasite antigen-specific cytotoxic T lymphocyte responses. J Clin Invest. 1998;102:1062-71.

\title{
Respuesta inmune innata y adquirida en la enfermedad de Chagas: modificación posterior al tratamiento
}

\author{
Manuel C. López¹, Ana Fernández-Villegas¹, Bartolomé Carrilero², Adriana Egui', Laura Montosa'1, \\ Concepción Marañón ${ }^{1}$, Manuel Segovia ${ }^{2}, \mathrm{M}^{\mathrm{a}}$ Carmen Thomas ${ }^{1}$ \\ 1 Instituto de Parasitología y Biomedicina López Neyra, Consejo Superior de Investigaciones \\ Científicas, Parque Tecnológico de Ciencias de la Salud, Granada, España \\ 2 Unidad de Medicina Tropical, Servicio de Microbiología, Hospital Virgen de la Arrixaca, El Palmar, \\ España
}

\section{Introducción}

Trypanosomacruzieselprotozooparásitocausante de la enfermedad de Chagas. Esta patología, endémica del continente americano, afecta con elevados índices de morbilidad y mortalidad a más de 10 millones de personas. Trypanosoma cruzi se transmite al huésped mamífero por una amplia variedad de insectos hematófagos cuyo hábitat es Centroamérica y Suramérica. La transfusión sanguínea, el trasplante de órganos, así como la transmisión oral son actualmente vías prevalentes de contagio $(1,2-4)$. Por otra parte, el intenso flujo migratorio de personas que viven en zonas endémicas, hacia el medio urbano y a países no endémicos ha hecho de la enfermedad de Chagas una patología global $(5,6)$.

La enfermedad de Chagas se inicia con una fase aguda que cursa con sintomatología inespecífica lo cual dificulta enormemente su detección. En ausencia de tratamiento, la mayoría de las personas no controlan la infección, permitiendo la supervivencia del parásito y su replicación en los tejidos. Estas personas desarrollan una fase crónica asintomática (fase indeterminada), 
que compromete cerca del $40 \%$ de los casos serológicamente positivos y que comprende periodos entre 10 a 25 años. Durante esta fase indeterminada de la enfermedad se establece un balance entre la respuesta inmune del huésped y el parásito. Este equilibrio es sumamente frágil, y frecuentemente se rompe, permitiendo la proliferación parasitaria en los tejidos y generando las patologías características de la fase crónica sintomática. Así, esta fase indeterminada deriva, en un alto porcentaje, en una fase crónica sintomática, caracterizada principalmente por la existencia de alteraciones cardiacas o digestivas, a la cual se asocia con una alta morbilidad (7). La quimioterapia actualmente disponible, aunque de cierta toxicidad, es efectiva en pacientes en fase aguda, controlando la enfermedad o disminuyendo la probabilidad de progresión a fase crónica, sin embargo, en la fase crónica de la enfermedad su efectividad no está aún sólidamente demostrada.

La respuesta inmune inducida por la infección de $T$. cruzi se caracteriza, en su etapa inicial, por una respuesta innata, seguida de la activación de linfocitos T CD4+ los cuales tienen un papel crucial en el control de replicación del parásito promoviendo la activación y proliferación de linfocitos T CD8+ y linfocitos B $(8,9)$. Como consecuencia de la respuesta desencadenada, el parásito pasa a ser combatido continuamente y su multiplicación en los tejidos del huésped vertebrado es reducida. Sin embargo, el parásito es capaz de persistir indefinidamente en el huésped, dado que puede contrarrestar las presiones selectivas generadas por los efectores celulares y humorales producto de la respuesta inmune desencadenada.

Las células dendríticas son células presentadoras de antígenos, cuya función se sitúa entre la respuesta inmune innata y la adaptativa. Son las únicas células capaces de activar los linfocitos $\mathrm{T}$ naive $\mathrm{y}$, por tanto, para la inducción de una respuesta efectora primaria. Las células dendríticas humanas se dividen en dos subpoblaciones, dotadas de distintos paneles de receptores de moléculas microbianas, entre ellos los llamados Toll-like receptor (TLR). Las células dendríticas mieloides $(\mathrm{mDC})$, producen grandes cantidades de IL-12 en respuesta a LPS (TLR-4) o lipopéptidos (TLR-2), lo que permite inducir una respuesta de tipo Th1. Las células dendríticas plasmocitoides (pCD) producen grandes cantidades de interferón de tipo I (IFNa y $\beta$ ) en respuesta a la estimulación por ARN viral (TLR-7) o ADN con motivos CpG no metilados (TLR-9). Trypanosoma cruzi posee el potencial para inducir la maduración de las mDC y pDC humanas mediada por TLR-2,4 y 9 (8). El equilibrio entre IL-12 e IL-10 es determinante para la polarización de los linfocitos $\mathrm{T}$ naive hacia un fenotipo Th1, Th2 o Treg. Por otra parte, las células dendríticas con actividad indoleamina 2,3dioxigenasa (IDO) inducen la tolerancia mediada por linfocitos T (10). En el modelo en ratones de infección experimental se ha encontrado una correlación entre la resistencia a la infección y la capacidad de las células dendríticas de expresar moléculas de coestimulación (11).

A pesar de los relevantes avances realizados al objeto de establecer la dinámica de la respuesta inmune antiparasitaria durante el desarrollo de la enfermedad de Chagas y determinar los patrones de respuesta inmunológica capaces de controlar la infección por T. cruzi, ambos aspectos siguen siendo objetivos por resolver. En este contexto, abordamos el estudio del reconocimiento, humoral y celular (CD8+) antígeno específico, por pacientes en distinta fase de cronicidad de la enfermedad de Chagas residentes en zona no endémica, y el estudio de la dinámica del nivel de reconocimiento de estos antígenos posterior al tratamiento con benznidazole. Asimismo, estudiamos en dichos pacientes, versus donadores sanos, la respuesta inmune innata (funcionalidad de TLR 2, 4, 9 y actividad IDO) y la posible reversión posterior al tratamiento de una potencial disfunción de ésta.

\section{Resultados}

Se pone en evidencia cómo distintas moléculas antigénicas de T. cruzi (KMP11, HSP70, PFR2, TgP63, TcCA-2), usadas como proteínas recombinantes o péptidos sintéticos y la metodología previamente descrita $(12,13)$, son específicamente reconocidas por sueros 0 células $T$ CD8+ de pacientes de Chagas (13,14, FernándezVillegas et al., BMC Infect Dis2011, sometido tras revisión; Egui et al., manuscrito en preparación). Interesantemente, alguna de estas moléculas es reconocida de forma diferencial dependiendo del estado de gravedad de la enfermedad (Thomas et al., manuscrito en preparación). Además, observamos cómo el nivel de reconocimiento de las moléculas identificadas es susceptible de ser modificado a cortos periodos de tiempo (90150 días) tras el tratamiento con benznidazol (Fernández-Villegas et al., BMC Infect Dis. 2011, sometido tras revisión) y de forma diferencial dependiendo del estadio de la enfermedad.

Asimismo, se observan determinados patrones de alteración de la respuesta innata (funcionalidad 
de los TLR, medida mediante el perfil de respuesta de las citocinas IFNa, IL-12, IL-6, IL-10, TNFa, IL$1 \beta$ y actividad indolamil-deoxigenasa) asociados a pacientes con la enfermedad de Chagas versus donadores sanos, los cuales se ven modificados tras el tratamiento con benznidazol (FernándezVillegas et al., manuscrito en preparación; Marañón et al., manuscrito en preparación). En algunos casos estas modificaciones se correlacionan con el estadio de la fase crónica de la enfermedad, así como con determinadas respuestas efectoras.

El estudio ha sido llevado en muestras biológicas de pacientes de Chagas con serología positiva (IFI y ELISA), en fase indeterminada y sintomática (sintomatología cardiaca y digestiva). Además, como grupo control se incluyen sujetos donadores sanos. Los pacientes con enfermedad de Chagas son tratados con benznidazole $(5 \mathrm{mg} / \mathrm{kg} /$ día, durante 60 días). Todos los pacientes y sujetos incluidos en el estudio aceptaron de manera voluntaria participar en el estudio y para ello firmaron el consentimiento informado. La significancia estadística se determinó mediante análisis no paramétricos -prueba $U$ de Mann-Whitney- y la prueba de los signos de Wilcoxon y el programa SPSS, versión 15.0).

\section{Referencias}

1. Pan American Health Organization Program. Regional de Chagas de la OPS. Fecha de consulta: 2011. Disponible en: http://www.paho.org/spanish/ $\mathrm{ad} / \mathrm{dpc} / \mathrm{cd} / \mathrm{dch}$-program-page.htm.

2. Lescure FX, Canestri $A$, Melliez $H$, Jaureguiberry $\mathrm{S}$, Develoux M, Dorent R, et al., Chagas disease, France. Emerg Infect Dis. 2008;14:644-6.

3. Piron M, Verges M, Munoz J, Casamitjana N, Sanz S, Maymo RM, et al. Seroprevalence of Trypanosoma cruzi infection in at-risk blood donors in Catalonia (Spain). Transfusion. 2008;48:1862-8.

4. Alarcón de Noya B, Díaz-Bello Z, Colmenares C, Ruiz-Guevara R, Mauriello L, Zavala-Jaspe R, et al., Large urban outbreak of orally acquired acute Chagas disease at a school in Caracas, Venezuela. $J$ Infect Dis. 2011;201:1308-15.
5. Jackson Y, Myers C, Diana A, Marti HP, Wolff H, Chappuis F, et al. Congenital transmission of Chagas disease in Latin American immigrants in Switzerland. Emerg Infect Dis. 2009;15:601-3.

6. Muñoz J, Coll O, Juncosa T, Verges M, del Pino M, Fumado V, et al. Prevalence and vertical transmission of Trypanosoma cruzi infection among pregnant Latin American women attending 2 maternity clinics in Barcelona, Spain. Clin Infect Dis. 2009;48:1736-40.

7. Prata A. Clinical and epidemiological aspects of Chagas disease. Lancet Infect Dis. 2001;1:92-100.

8. Tarleton RL. Immune system recognition of Trypanosoma cruzi. Curr Opin Immunol. 2007;19:430-4.

9. de Meis J, Morrot A, Farias-de-Oliveira DA, VillaVerde DM, Savino W. Differential regional immune response in Chagas disease. PLoS Negl Trop Dis. 2009;3:e417.

10. Mellor AL, Chandler P, Lee GK, Johnson T, Keskin $\mathrm{DB}$, Lee $\mathrm{J}$, et al. Indoleamine 2,3-dioxygenase, immunosuppression and pregnancy. J Reprod Immunol. 2002;57:143-50.

11. Planelles L, Thomas MC, Marañón C, Morell M, López MC. Differential CD86 and CD40 co-stimulatory molecules and cytokine expression pattern induced by Trypanosoma cruzi in APCs from resistant or susceptible mice. Clin Exp Immunol. 2003;131:41-7.

12. Thomas MC, Longobardo MV, Carmelo E, Marañón C, Planelles L, Patarroyo ME, et al. Mapping of the antigenic determinants of the T. cruzi kinetoplastid membrane protein-11. Identification of a linear epitope specifically recognized by human Chagasic sera. Clin Exp Immunol. 2001;123:465-71.

13. Marañón $C$, Egui $A$, Carrilero B, Thomas MC, Pinazo MJ, Gascón J, et al. Identification of HLA-A*02:01restricted CTL epitopes in Trypanosoma cruzi heat shock protein-70 recognized by Chagas disease patients. Microbes Infect. 2011; en prensa.

14. López MC, Fernández-Villegas A, Marañón C, Carrilero B, Pinazo MJ, Gascón J, et al. Nuevos indicadores serológicos. Enfermedades Emergentes 2011;13:50-4.

\section{Financiación}

El presente trabajo ha sido financiado por los proyectos P08-CVI-04037PAI (Junta de Andalucía) y RD06/0021/0014 - ISCIII-RETIC (MICINN) - FEDER. 